\title{
Discussion on the MCU Course Reform Based on the Cultivation of Students' Innovation Ability
}

\author{
Hong Guo* and Hanjing Cui \\ College of Computer Science and Technology, Wuhan University of Science and Technology, Wuhan 430065 \\ *Corresponding author. Email: guohong@wust.eud.cn
}

\begin{abstract}
This paper combined with the teaching reform and practice of "Single-chip microcomputer Principle and Application" course for electrical majors in colleges and universities, puts forward a new single-chip microcomputer course teaching system based on cultivating students' ability of innovation and entrepreneurship, effectively bringing up classroom teaching, experimental teaching, curriculum design and graduation design. The electronic competition is organically integrated, highlighting the feedback function of circulation and achieving an integrated teaching mode of viewing, listening, acting, and competition. This not only improves the teaching quality of the SCM course, but also cultivates students' innovative awareness and engineering practice ability.
\end{abstract}

Keywords: SCM curriculum, Teaching reform, Innovation ability.

\section{NECESSITY OF CARRYING OUT TEACHING REFORM OF SCM COURSE}

Innovation and entrepreneurship is an important manifestation of the overall quality of students, and it is also an important measure of the quality of personnel training [1]. Universities and colleges actively carry out innovation and entrepreneurship education, and cultivate a new generation of compound entrepreneurial talents with innovative spirit, entrepreneurial awareness and entrepreneurial ability. Encouraging students to start their own businesses and actively building innovative countries are the needs of the times and the need for personnel training.

In the daily teaching activities, training students' ability of innovation and entrepreneurship, the curriculum is an important carrier [2]. At present, the SCM control technology has been increasingly integrated into the human society. SCM has the characteristics of low cost, small size, and strong functions. It is widely used in industrial control, smart meters, energy-saving technological transformation, signal processing and household appliances, etc. The application and practice of SCM is a good platform to promote students' innovation and entrepreneurship [3]. Based on the characteristics of SCM, this paper carries out the reform of teaching model aiming at cultivating students' ability of innovation and entrepreneurship. It explores integrating the content of innovation and entrepreneurship into the teaching of SCM, and links the teaching activities of the course with the improvement of students' ability for innovation and entrepreneurship [4].

The teaching materials used in the current singlechip microcomputer courses overemphasize the integrity of the knowledge system. Theoretical teaching and experimental teaching are carried out at different places and at different times, causing the phenomenon of disconnection between teaching and experiment. The experiments in the laboratory are mostly theoretical verification tests, which are carried out in accordance with the steps on the experiment box. The experiment content is simple, the realized functions are limited, the project design experiment cannot be realized, and the innovative personality design is lacking [5].

The single-chip microcomputer course has strong comprehensive and practical characteristics, and is a good platform for cultivating students' innovation and entrepreneurship capabilities. Traditional SCM course teaching often ignores the characteristics of SCM application, does not integrate innovation and entrepreneurship education into the whole process of course teaching, and pays attention to the cultivation of students' innovation and entrepreneurship ability.

How to eliminate these unfavourable factors and make the curriculum a good soil, tool and platform for students' innovation and entrepreneurship education is 
the focus of the reform of the teaching model of the single-chip microcomputer curriculum.

\section{THE CURRICULUM SYSTEM AND CHARACTERISTICS OF SCM COURSE}

The single-chip microcomputer course is a required course for the electricity major in colleges and universities. Its teaching emphasizes the application and practicality. The knowledge structure of the SCM course can be divided into three modules [6,7]: the leader module, the core module, and the extension module, and the three modules are progressive, as shown in Figure 1. The single-chip microcomputer principle is the most important course of the core module. It is the only way for simple electronic circuit design to move towards the design of complex electronic systems and complete systems. It is the key to transition from curriculum design to graduation design, student scientific research, subject competition, and technical development after graduation. node. On the other hand, the principles of the SCM are different from those of the automatic control principle, and cannot be separated from the entire SCM application system. This requires the teacher to teach knowledge points and practical skills from the system point of view during the course of teaching to remind the students of knowledge. The internal connection, so that students understand, what is the use of SCM? How to use? Instead of simply dealing with the exam, passively accept it.

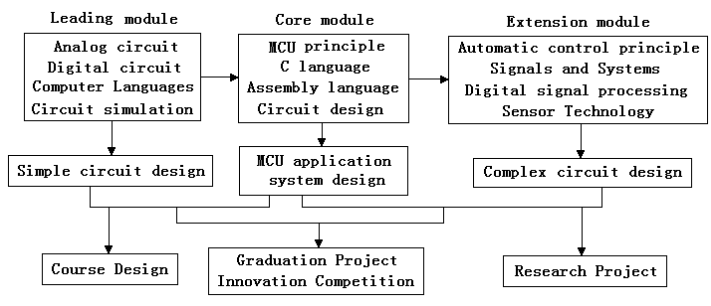

Figure 1 Knowledge Structure of SCM Course

To achieve the above requirements, we must grasp the characteristics of the SCM course in teaching as an innovative practice course. The SCM course includes the following features:

(1) The single-chip microcomputer course is highly integrated. Its lead courses include "Analog electronic technology", "digital electronic technology", "computer programming language", and "circuit simulation technology". If the previous courses are not well studied, they will be taught on a one-chip computer program. Learning has caused obstacles. Therefore, teachers who teach SCM courses should strengthen the review and contact of the previous courses during the lectures.

(2) The integrated and flexible use of SCM technology has far-reaching significance for the expansion and realization of students' innovative capabilities. The SCM control technology has become more and more integrated into the human society. Therefore, a good product or life idea is And ultimately, SCM control.

(3) The acceptability of theoretical knowledge of single-chip computer curriculum is poor. In the teaching process, students' understanding of theoretical knowledge is not thorough, which makes students subjectively feel that the relevance between curriculum and professional is not strong. Therefore, we do not want to study in depth when we encounter problems, but the development of new technologies has not allowed us to ignore the widespread application of electronic technologies.

(4) The single-chip microcomputer course has strong practicality. Since the single-chip microcomputer course has been separated from the experiment and practice links, the course has lost its original meaning and it has not been applied. The teaching of the single-chip microcomputer course will be meaningless.

(5) The SCM control technology is updated quickly. The performance of the SCM continues to advance and improve with the development of microelectronics technology. In theory teaching, it is necessary to constantly update teaching materials and teach new models so that students can master the latest theory and technology of the SCM.

How to better open a SCM course in the electrical specialty of colleges and universities, how to combine with the teaching of SCM to better improve the students' ability to innovate, this problem needs to be solved.

\section{ESTABLISH A CURRICULUM SYSTEM FOR THE CULTIVATION OF INNOVATIVE ABILITY}

\subsection{Reasonably divide course modules}

The teaching reform of single-chip microcomputer should start from the teaching system of the single-chip computer course [8]. Our school has rebuilt the teaching system of the single-chip microcomputer course based on the goal of cultivating innovative and entrepreneurial talents. as shown in figure 2. The curriculum system includes compulsory modules and elective modules. The compulsory modules consist of theoretical teaching, experimental teaching, autonomous learning, and course design. In the fifth semester, students completed the theoretical teaching, experimental teaching, and independent learning of the SCM. Before the winter vacation, the course design was suspended within two weeks of the short semester; the elective module was composed of student scientific research, subject competition, graduation design, and participation in 
teachers' scientific research projects. Students choose. Starting from the fifth semester, students participate in the scientific research projects of students at all levels by hosting and participating in school, provincial, and national level electronic design competition for undergraduate students, selecting topics for the graduation design of SCM applications to further consolidate the learning outcomes and enable students to have a certain degree of SCM development. Competencies, in which students learn to take advantage, can also participate in teachers' scientific research projects and develop their engineering practice capabilities [9].

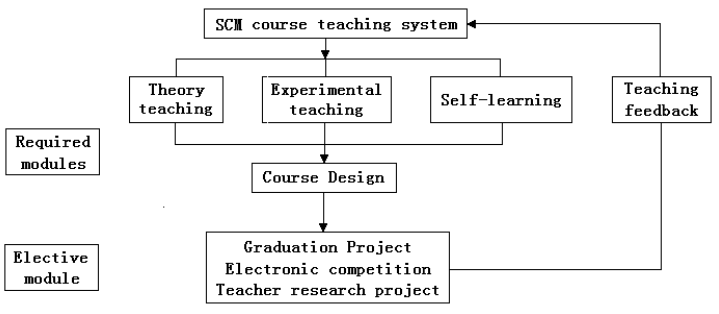

Figure 2 SCM course teaching system

\subsection{Selection of course content}

It should be up-to-date and forward-looking in the selection of teaching materials and course content. The single-chip microcomputer is an application-oriented special computer system, which is closely related to the product and the market. The innovation of the design directly determines the innovation of the product. The content of the course should reflect the current hot spots in the field of single-chip microcomputers, and the core technologies that enterprises generally care about must have strong practicability, which is conducive to cultivating talents needed by the industry. With the gradual elimination of 51 single-chip microcomputers, the current 16-bit single-chip microcomputer has gradually become the mainstream. TI's MSP430 is the representative product of the current 16-bit computer, and its application fields are becoming wider and wider. Therefore, this course selects TI's latest product series MSP430F55/66xx as the teaching content of this course.

\subsection{Refinement of the assessment system}

In order to ensure the smooth implementation of the above-mentioned curriculum system, the assessment system has been refined, paying attention to students' usual mastery of knowledge and skills, highlighting practicality, and reducing the assessment of memorable content. The proportions of each part of the assessment items are shown in Table 1.
Table 1. SCM Course Evaluation System

\begin{tabular}{|c|c|c|c|c|}
\hline Assessment subjects & Item one & Item two & Item three & Item four \\
\hline $\begin{array}{l}\text { SCM theory } \\
\text { teaching } \\
\text { (56 class hours) }\end{array}$ & $\begin{array}{l}\text { Final exam } \\
(60 \%)\end{array}$ & $\begin{array}{c}\text { Normal } \\
\text { homework } \\
(20 \%)\end{array}$ & $\begin{array}{c}\text { Mid-term exam } \\
(10 \%)\end{array}$ & $\begin{array}{c}\text { Normal } \\
\text { performance } \\
(10 \%)\end{array}$ \\
\hline $\begin{array}{l}\text { SCM experiment } \\
\text { teaching } \\
\text { (30 class hours) }\end{array}$ & $\begin{array}{c}\text { Normal } \\
\text { performance } \\
\text { results } \\
(60 \%)\end{array}$ & $\begin{array}{c}\text { Experimental } \\
\text { exam } \\
(40 \%)\end{array}$ & & \\
\hline $\begin{array}{l}\text { SCM Course } \\
\text { Design } \\
\text { (Classes are } \\
\text { suspended for } 2 \\
\text { weeks) }\end{array}$ & $\begin{array}{l}\text { Course } \\
\text { Design } \\
\text { Report } \\
(40 \%)\end{array}$ & $\begin{array}{c}\text { In kind } \\
(30 \%)\end{array}$ & $\begin{array}{l}\text { Reply } \\
(20 \%)\end{array}$ & $\begin{array}{c}\text { Usual } \\
\text { performance } \\
(10 \%)\end{array}$ \\
\hline
\end{tabular}

In the examination part of theoretical teaching, avoid investigating the contents of students' mechanical memory, such as the address mapping of each addressable bit of the MSP430 special function register, various control words of the clock module and timer, etc., if necessary, it is recommended It is given on the test paper in the form of an appendix, focusing on the application level.

Pay attention to the students' self-learning in daily homework and performance. Appropriate extended questions can be arranged. Students can only complete them by consulting reference books or searching on the Internet. Strengthen the interactive links in the classroom, so that every student has a question and answer in the classroom. Opportunities arouse the attention of students and avoid self-directed learning as a formality.

The usual experimental results include experimental operations $(50 \%)$, experimental reports $(30 \%)$, and experimental previews (20\%). The investigation of experimental operations requires teachers to refine the assessment criteria, which can be divided into grammar, software application, debugging skills, experimental results, Questions and other links.

Design the experiment examination question selection software, randomly choose 1 question from 10 questions, the examination questions are from the usual 10 experiments, so that students will pay more attention to the usual experiments, and the experimental teaching should be set up separately to avoid becoming an accessory to the theoretical teaching.

The curriculum design of the single-chip microcomputer requires students to complete a practical but not high-complexity subject. It requires modules such as signal conditioning, data display, and keyboard. The students complete welding and program debugging on the experiment board.

\subsection{Emphasize innovation and hands-on ability}

In the teaching process of the above compulsory modules, teachers actively introduce to students the mainstream technology and latest developments in the 
field of microcontrollers, such as system-on-chip microcontrollers PIC24F series, STM32F series, and ARM series processors. At the same time, combined with the teacher's scientific research, create conditions for students to demonstrate the practice of microcontrollers. Engineering application stimulates students' interest in learning. Encourage students to participate in school electronic design competitions, discover outstanding students in school competitions, and form teams to participate in municipal, provincial, and national electronic design competitions. About 50\% of the students majoring in computer science and technology where the author participates in school competitions, and $20 \%$ of students participate in higherlevel competitions. Among the outstanding students, they will also form a research team to apply for provincial and municipal university students' scientific and technological innovation projects. Under the guidance of teachers, they will complete the design of a number of practical projects [10].

\section{PAY ATTENTION TO CULTIVATING STUDENTS' INNOVATIVE ABILITY AND ENGINEERING QUALITY}

\subsection{Establish experimental teaching module system}

"Principle and Application of Single Chip Microcomputer" is a highly technical and applicable subject, and experiment teaching is an extremely important part of it. In the single-chip experimental system, combined with years of practice, summarized and innovated, and proposed that experimental teaching should be combined with theoretical teaching, starting from reality, focusing on the cultivation of students' innovative ability, stimulating students' interest in practical teaching, and comprehensive, systematic and effective teaching implementation. The plan is to be carried out in stages. To this end, the experimental teaching module system that adapts to the level and characteristics of our school's students is summarized, as shown in Figure 3.

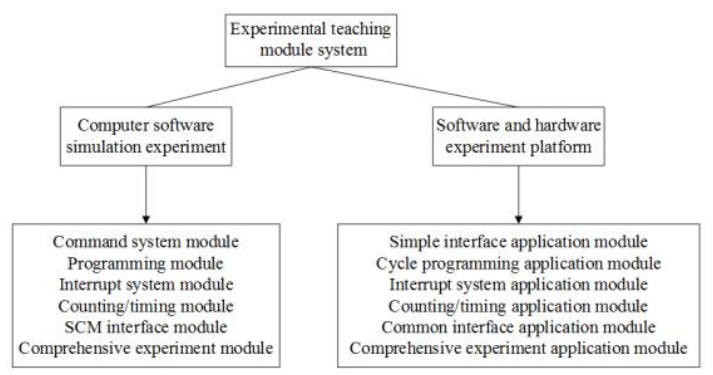

Figure 3 Experimental teaching module system

The whole experimental system is divided into two parts, one is to use the currently popular "Weifu" simulation software or use the "Keil" simulation software to carry out software simulation and debugging of the program. The second is to use TI's MSP430F6638 development board, combined with the requirements of the experiment topics, design, wire, program, debug, program download and other software and hardware integration processes. The entire experimental system has the following characteristics: (1) Computer software simulation module experiment is the basis of the soft and hard platform experimental modules; (2) Each submodule is a relatively independent training focus, which is a method or technology of single-chip application design; (3) Each sub-module There is a hierarchical structure between the upper and lower modules. In addition to accomplishing its own teaching purposes, the results produced by the upper modules are the working foundation of the lower modules. The following experiments are expanded and extended on the basis of the previous experiments; (4) In terms of experimental content, It is no longer a purely confirmatory experiment, but supplemented by a comprehensive and design experiment; (5) Supervise students to pay attention to the preview of the experiment, record the experiment process, and require the experiment report to be standardized, tidy, logical, and profound in summary or experience; (6) Experimental performance assessment consists of two parts: usual experiment and experimental report scores, which assess students' mastery of basic knowledge, experimental ability, comprehensive application of knowledge ability, and usual performance.

This kind of hierarchical structure is conducive to students from shallow to deep, gradually learn to use knowledge comprehensively, and finally master the basic knowledge, key technologies and methods of MCU application as a whole, and enhance students' enthusiasm and sense of responsibility for experiment With a sense of urgency, students' hardware hands-on ability and programming skills have been significantly improved [11].

Practice has proved that with the establishment and implementation of the experimental teaching module system, students' theoretical knowledge, basic experimental skills and engineering awareness have been well mastered and improved, and students' learning initiative has generally improved.

\subsection{Strengthen the course design link}

The purpose of the course design of "Single-chip Microcomputer Principles and Applications" is to enable students to complete a design and programming application of a small system target board with comprehensive functions involving MSP430 single-chip microcomputer multiple resource applications on the basis of theoretical learning. Not only can the theoretical knowledge learned in the classroom be combined with practical applications, but also the comprehensive 
application of knowledge in electronic circuits, electronic components, circuit wiring, etc., and at the same time in software programming, debugging, welding technology, and related equipment The use of skills and other aspects have been more comprehensively trained and improved, which will lay a certain foundation for the independent development and design of the single-chip application system in the future [12].

The course design time is generally only 1 to 2 weeks, and the difficulty of the topic should not be too high, but it must have a certain breadth, have a certain representativeness, and be able to include all the main links of the course. In the topic selection, students are required to combine their usual study and data collection, choose the topic by themselves, or choose the topic assigned by the teacher, and the students can analyze and design the topic by themselves, program, debug, install, weld and finally debug to complete a single-chip microcomputer. The application system must understand and digest the relevant classroom teaching content involved in the design process, and the final submission is the physical object and the design report.

The purpose and requirements of the subject are: (1) Able to master the methods and steps of actual system development using single-chip microcomputer. (2) Able to further master the writing of interrupt system and its service program. (3) Able to master the timing system, the calculation and loading of the initial value of the count, etc. (4) Able to master the application of MCU interface. (5) Able to master hardware design and welding process requirements. (6) Able to master the design, writing, debugging and program curing of the assembler of the single-chip microcomputer. (7) Request to write a course design report, analyze the results, phenomena, experience and gains of your own operation during the design process.

In the design process, we should learn to deal with and solve flexibly the problems that should be paid attention to and the problems that may arise in each link. What's more important is to let students experience the hardships of each link by themselves. This not only helps students understand the important role of various knowledge, but also helps them develop their ability to solve problems and social interactions from the practical perspective. Not to "talk on paper." Practice has proved that this kind of curriculum design is very welcome to students, and the learning effect is remarkable.

\subsection{Strengthen graduation design and engineering design}

Theory guides practice and practice tests theory. In the graduation design, instructors are required to focus on the cultivation of students' engineering abilities and innovative consciousness, starting from the topic selection, aiming at the dynamics of the subject development and practical application issues, so that the graduation design topics have new ideas and implementation methods. The breakthrough has fully mobilized the enthusiasm of the students, and students must be allowed to do real problems in the design and design with real skills [13]. In the graduation design of electrical majors, application development using singlechip microcomputer as a tool is very common, and students' interest and employment needs are quite high. The "Analysis and Design of Large-screen Display Control System" and "Single-chip Temperature Detection and Control system", "Single-chip multifunction clock system", "IC card reader", "elevator control system" and other graduation design topics, aiming at students' interest and employment needs, combining theory with practice, and training students' solid professional knowledge and abilities. Received unanimous praise from teachers and students.

At the same time, strict requirements must be imposed during the graduation design process. Formulated graduation design regulations, graduation design thesis workflow, graduation design grading standards. Each student has 30 minutes to defend the thesis. The students who are recommended by the instructor and who are invited for the excellent evaluation must give a unified defense in the teaching and research section. This puts forward higher requirements for students and instructors, and also promotes the teaching of teachers.

\subsection{Applying for Innovation Projects and Participating in Professional Competitions}

Actively and extensively carry out extracurricular practical activities. At present, most of the electronic design competition topics are handled by single-chip microcomputers. In the student innovation competition held every May in our school, the Institute of Electronics has organized and participated in the competition well. For example, there were 22 design projects in the school this year. On this basis, organize and encourage students to participate in various electronic design competitions organized by provinces, cities, and the whole country, and support the practical activities of school and department students' electronic society. These measures have exercised students well, made them brave to get out of the classroom and out of the school, and have also greatly promoted the teaching reform of the curriculum.

\section{CONCLUSION}

In recent years, through the teaching and practice reforms of the "Principles and Applications of SCM" curriculum, our school has significantly improved the 
quality of teaching, broadened the knowledge of students, and improved the interest of students in learning professional courses. It not only gained training and improvement in engineering practice ability. Moreover, it has cultivated innovative thinking and creative ability, realized the cultivation of its own innovation and entrepreneurial ability, and also provided a good learning foundation and learning method for follow-up professional course study and practice. The course teaching mode of the new single-chip microcomputer course teaching system has shown good practice results after the examination of teaching practice in recent years. It relies on the teaching practice reform of single-chip microcomputer to promote the cultivation of students' innovative ability, and also has teaching for other professional courses. Big promotion value.

\section{ACKNOWLEDGMENTS}

*Funded Project: Teaching and Research Project of Wuhan University of Science and Technology (No.2020x044).

\section{REFERENCES}

[1] J. Y. Xu, Z. X. Li, Z. D. Cai. SCM Teaching Reform and Practice Based on the Open Engineering Project. Journal of Huzhou Teachers College, 2017, 39(6): 60-64

[2] P. Lin, D. Li, S. C. Jiang, D. Y. Wang, Y. M. Chen. Research on Teaching Reform of Single Chip Microcomputer Excellent Course in Applied Undergraduate. Modern Vocational Education, 2019, (7): 100-101.

[3] Y. Yang, W. J. Yang, Y. F. Chen. Cultivation of Innovation and Entrepreneurship Competence of Collage Students: Reform of Teaching Model on MCS51 Course. Journal of Guangzhou City Polytechnic, 2017, 11(3): 57-59.

[4] S. M. Jiang, C. L. Zhao, L. Fu. Teaching Reform and Practice of Single-Chip Microcomputer Course under the Background of Engineering Education Professional Certification. China Modern Educational Equipment, 2020, (21): 28-31.

[5] M. Yu. Teaching Reform and Exploration Research on "Single Chip Microcomputer Principle and Application" in Mechanical and Electronic
Engineering Major in Beijing University of Civil Engineering and Architecture. Education and Teaching Forum, 2018, (46): 168-170.

[6] M. X. Jin, S. H. Zhu, T. Wang, Q. Zhang. Practice and Reformation of Principle and Application of Single Chip Microcomputer. Industrial Control Computer, 2020, 33(3): 145-146,148.

[7] Y. C. Wang, Y. Qin, J. S. Zhang, F. Z. Wang. Research and Practice on Teaching Reform of "Single-Chip Microcomputer Principles and Applications" Based on Application-oriented Talent Cultivation. Information \& Communications, 2017, (11): 260-261.

[8] L. Tang, X. Y. Liu, X. L. Liao, Y. X. Zhao, Y. P. Li. Research on SCM experiment teaching based on combination of simulation and experiments. Experimental Technology and Management, 2019, 36(4): 213-216.

[9] W. H. Zeng. Teaching Reform and Practice of Principle of Single Chip Microcomputer and Application Course. Journal of Electrical \& Electronic Education, 2018, 40(5): 65-67, 97.

[10] X. Wang, Z. Hua, G. F. Wei, Y. Q. Wang, Y. W. Liu, F. G. Yang. Research and Exploration on the Practical Ability Training Mode of Electronic Information Specialty in Local Universities under the Background of New Engineering. China Modern Educational Equipment, 2019, (23): 104 106.

[11] R. M. Lou, S. L. Wang. Reform of Practice Teaching of Single Chip Microcomputer and Cultivation of Applied Talents. China University Teaching, 2009, (3): 80-81.

[12] H. Y. Ma, F. Z. Song, M. W. LI, Y. R. Yang, W. Y. Zhang. Study on the Cultivation System of College Students' Innovation and Entrepreneurship Ability Driven by Technological Innovation Competitions. Education and Teaching Forum, 2020, (23): 91-93.

[13] L. Yu, C. B. Hou, X. D. Wang. Research and Practice on the Teaching Mode of Electronic Practice Courses Under the Background of Engineering Education. Experiment Science and Technology, 2020, 18(1): 58-62. 